\title{
TAKEMITSU TŌRU I JEGO MUZYKA - CZY ABY NA PEWNO JAPOŃSKA?
}

\author{
MAEGORZATA WOLNIAK ${ }^{1}$ \\ (Uniwersytet im. Adama Mickiewicza w Poznaniu)
}

\begin{abstract}
Słowa kluczowe: Takemitsu Tōru - muzyka japońska - współcześni japońscy kompozytorzy estetyka w muzyce japońskiej - sawari - ma
\end{abstract}

Key words: Takemitsu Tōru - Japanese music - contemporary Japanese composers -

Japanese music aesthetics - sawari - ma

\begin{abstract}
Abstrakt: Małgorzata Wolniak. TAKEMITSU TŌRU I JEGO MUZYKA - CZY ABY NA PEWNO JAPOŃSKA? PORÓWNANIA 18, 2016. T. XVIII. S. 283-305. ISSN 1733-165X. Takemitsu Tōru jest jednym z najbardziej znaczących kompozytorów japońskich dwudziestego wieku. W artykule opisane zostały jego kariera, twórczość oraz inspiracje. Kompozytor zasłynął z łączenia elementów tradycyjnej muzyki japońskiej z zachodnią kompozycją. Styl ten nie zawsze jednak był jego znakiem rozpoznawczym, a powstał dopiero po latach poszukiwań i rozważań na temat estetyki i teorii muzyki. W ostatniej części artykułu przedstawiona została estetyka twórczości Takemitsu, która podkreśla jego, odmienny do zachodniego, japoński sposób pojmowania muzyki.
\end{abstract}

\begin{abstract}
Małgorzata Wolniak. TAKEMITSU TŌRU AND HIS MUSIC - IS IT REALLY JAPANESE (AFTER ALL)? COMPARISONS 18, 2016. Vol. XVIII. P. 283-305. ISSN 1733-165X. Takemitsu Toru is one of the most prominent and recognizable Japanese contemporary composers. The composer is famous for his skill of combining the elements of traditional Japanese music with Western style composition. The article presents his career, inspirations, Japanese aesthetics such as ma and sawari. His perception of music and his relation to Japanese music and traditional instruments in comparison to the Western music traditions is also described.
\end{abstract}

${ }^{1}$ E-mail Address: malgorzata.wolniak@gmail.com 
Japoński kompozytor Takemitsu Tōru (1930-1996) jest najbardziej barwnym, znanym i szanowanym na świecie współczesnym kompozytorem japońskim². Przez sześćdziesiąt sześć lat swojego życia zdobył wielkie uznanie jako autor muzyki filmowej, licznych esejów na temat muzyki. Przede wszystkim jednak zasłynął jako twórca utworów w stylu klasycznym. Z perspektywy tradycji Zachodu kompozycje Takemitsu można uznać za wzorcowy przykład japońskiej muzyki XX wieku. Jego wyjątkowy styl wynika $z$ umiejętnego, efektownego splecenia cech muzyki zachodniej i rodzimej.

\section{Rozwój twórczości Takemitsu Tōru}

\section{Początki kariery}

Takemitsu Tōru urodził się 8 października 1930 roku w Tokio. Miesiąc później jego rodzina przeniosła się do chińskiego miasta Dalian, w Mandżurii, gdzie pracował ojciec, Takemitsu Takeo, wielki miłośnik amerykańskiej muzyki jazzowej. Dzięki temu Tōru od najwcześniejszych lat często miał okazję przysłuchiwać się nagraniom jazzu, który najprawdopodobniej był pierwszym źródłem jego inspiracji Zachodem. Po latach, w rozmowie z Ozawą Seijim (ur. 1935), Takemitsu żywo wspomina doświadczenia z dzieciństwa: „wewnątrz mnie wciąż pozostaje trochę tej jazzowej muzyki" (Takemitsu 1981: 21)33. Trudno się z tym nie zgodzić, nie tylko przez wzgląd na kompozycje, w których jazz obecny jest w sposób bezpośredni, podany $\mathrm{w}$ formie parodii. Ślady jazzowego brzemienia wychwycić można również w łagodnym języku harmonicznym Takemitsu.

Być może dziecięce doświadczenia zaważyły na całej twórczości kompozytora - pozytywna reakcja na muzykę zachodniego pochodzenia wiązałaby się z miłymi wspomnieniami z dzieciństwa, a krytyczny stosunek Takemitsu do tradycyjnej muzyki japońskiej wynikałby $\mathrm{z}$ trudnych doświadczeń późniejszego okresu. W wieku siedmiu lat Takemitsu został odesłany do Tokio, by tam zacząć szkołę podstawową. Jego ojciec, z powodu złego stanu zdrowia, dołączył do niego rok później i zmarł w 1938 roku. Takemitsu zamieszkał u swojego wujka, którego żona, ciotka Takemitsu, była nauczycielką gry na cytrze koto ${ }^{4}$, w związku z czym w domu cały czas pobrzmiewały dźwięki tego tradycyjnego instrumentu japoń-

${ }^{2}$ Na temat twórczości Takemitsu istnieje kilka obszernych prac anglojęzycznych, głównie o charakterze muzykologicznym (zob. np.: P. Burt, The Music of Tōru Takemitsu. Cambridge, 2001). W języku polskim nie ma jednak żadnych opracowań, mimo że utwory tego kompozytora są stosunkowo dobrze znane.

${ }^{3}$ Wszystkie cytaty zostały przetłumaczone z języka japońskiego przez autorkę artykułu.

${ }^{4}$ Koto - tradycyjny trzynastostrunowy japoński instrument szarpany, rodzaj cytry. 
skiego (Burt 22). Być może skojarzenie z tym trudnym okresem w życiu Takemitsu było powodem, dla którego był on uprzedzony do muzyki japońskiej. W jednej z rozmów kompozytor przyznaje: „Słyszałem wokół mnie tradycyjną muzykę japońską cały czas. $Z$ jakiegoś powodu nigdy do mnie nie ona przemawiała, nigdy mnie nie poruszyła. Później muzyka ta zawsze przywoływała we mnie gorzkie wspomnienia wojny" (Takemitsu 1989: 205-214).

W roku 1944 Takemitsu został przymusowo powołany do służby wojskowej w jednostkach rezerwowych w prefekturze Saitama. To doświadczenie kompozytor wspomina jako bolesne. W okresie wojny zachodnia muzyka popularna była w Japonii zakazana, jednak gdy w tajemnicy, słuchając wraz z kolegami płyt gramofonowych, Takemitsu usłyszał śpiewaną przez Lucienne Boyer (1903-1983) francuską piosenkę Parlez-moi d'amour został nią oczarowany (Takemitsu 1989: 205-214). Muzyka zachodnia była atrakcyjna, emocjonująca i stanowiła wyraźny kontrast $\mathrm{w}$ stosunku do patriotycznych pieśni, które wszędzie było słychać. To zapewne dlatego właśnie tę sentymentalną piosenkę Takemitsu określa jako bezpośredni bodziec do podjęcia decyzji o zostaniu kompozytorem (cyt. za: Burt 23).

Takemitsu nie odebrał żadnego muzycznego wykształcenia, ale swoje wczesne próby kompozytorskie podejmował pod wpływem różnych inspiracji. Istotną rolę w jego początkowym życiu zawodowym odegrał Hamada Tokuaki (lata życia nieznane), kierownik chóru amatorskiego, do którego Takemitsu należał pewien czas. W chórze tym poznał też młodego kompozytora, Suzukiego Hiroyoshiego (ur. 1931) i na trwałe się z nim zaprzyjaźnił. Wspólnie studiowali udostępniane im przez Hamadę różne utwory francuskie czy Rimskiego-Korsakova (1844-1908). Obaj (wraz z Suzukim) podejmowali próby kompozytorskie, starając się wzorować na muzyce europejskiej i amerykańskiej (Burt 24).

Takemitsu, mimo nabywanych doświadczeń, pozostawał krytyczny wobec japońskiej tradycji muzycznej. Jako siedemnastolatek był przerażony, kiedy zdał sobie sprawę z tego, że w jednym z własnych utworów, Kakehi (Przewód, 1947), zastosował elementy typowej dla rodzimej muzyki propagandowej skali pentatonicznej. $Z$ obawy przed tym, że utwór ten mógłby być postrzegany jako nacjonalistyczny, zniszczył go (Takemitsu 1985: 95).

Wkrótce potem (1948), podczas Japońsko-amerykańskiego Festiwalu Muzyki Współczesnej (Nichi-Bei Gendai Ongaku Matsuri), Takemitsu został przedstawiony Kiyose Yasujiemu (1900-1981). Ten powszechnie znany z „nacjonalistycznych skłonności" kompozytor przyjął i Takemitsu, i Suzukiego na swoich uczniów (Burt 23). Mimo to Takemitsu, pytany o naukę kompozycji i o swoją edukację muzyczną, zawsze określał siebie jako samouka, akcentując, że swoim mentorom zawdzięczał ewentualnie tylko poszerzenie muzycznych horyzontów ${ }^{5}$.

${ }^{5} \mathrm{~K}$. Witt. "Toru Takemitsu: My music is like a garden, and I am the gardener". Soundtrack! Magazine, 1996. Wywiad przeprowadzony przez Karsten Witt, Wiedeń, 4.11.1993. 
Takemitsu, będąc pod skrzydłami Kiyose, został przedstawiony wielu starszym kompozytorom z "nacjonalistycznego" kręgu kompozycji, takim jak Yoritsune Matsudaira (1907-2001) i Hayasaka Fumio (1914-1955). Dzięki tym znajomościom został członkiem Szkoły Nowej Kompozycji (Shinsakkyokuha) ${ }^{6}$, skupiającej japońskich twórców o nacjonalistycznych poglądach. Podczas siódmego koncertu (w grudniu $1950 \mathrm{roku}$ ) przedstawicieli tego ugrupowania po raz pierwszy wykonano utwór Takemitsu Lento in Due Movimenti ${ }^{7}$. Został on jednak chłodno przyjęty i spotkał się z gorzkim komentarzem, że to "premuzyka” (Burt 23).

\section{Działalność stowarzyszenia Jikken Kōbō i inspiracje muzyką zachodnią}

Pierwsza publiczna prezentacja utworu Takemitsu miała jednak również pozytywne konsekwencje. Tego wieczoru muzyk nawiązał znajomość z kompozytorem Jōji Yuasą (ur.1929) oraz Kimaharu Akiyamą (1926-1996) - poetą i krytykiem muzycznym. We wrześniu 1951 roku w wyniku spotkań z tymi, a także z innymi twórcami zapadła decyzja o powołaniu do życia artystycznego stowarzyszenia, które miało urzeczywistniać ich wspólne estetyczne ideały (Burt 39). Powstało zatem towarzystwo Warsztat Eksperymentalny (Jikken Kōbō) realizujące, zgodnie nazwą, nowatorskie pomysły i stanowiące wyróżniający się akcent na tle japońskiej awangardy.

Po wstąpieniu do tego ugrupowania Takemitsu wystąpił ze Szkoły Nowych Kompozytorów. Miało to dalekosiężny wpływ na jego twórczość. Szczególne znaczenie odegrały dwa założenia programowe. Pierwsze z nich polegało na zdecydowanym odrzuceniu akademickich zasad muzycznych i na traktowaniu - jak można odnieść wrażenie - formalnego wykształcenia muzycznego jako przeszkody do uzyskania członkostwa w stowarzyszeniu (Burt 39). To zapewne pomogło wzmocnić pozycję Takemitsu w wysoce sformalizowanym i hierarchicznie zorganizowanym świecie japońskiej kultury. Zgodnie z drugim założeniem stowarzyszenia, w przeciwieństwie do konserwatywnego programu Szkoły Nowych Kompozytorów, celem Warsztatu Eksperymentalnego było zrzeszenie artystów reprezentujących różne dziedziny i umożliwienie im interdycyplinarnej wymiany myśli (Burt 39). Ten aspekt stowarzyszenia wydaje się również znaczący dla Ta-

${ }^{6}$ W skład ugrupowania wchodzili: Kiyose Yasuji, Yoritsune Matsudaira, Hayasaka Fumio, Ōtsuki Kunio (1911-1991), Tsukuatani Akihiro (1919-1995) i inni.

7 Wszystkie niejapońskojęzyczne tytuły utworów Takemitsu Tōru podano zgodnie z oryginalnym zapisem przyjętym przez kompozytora. Tytuły japońskojęzyczne podano, posługując się międzynarodową transkrypcją Hepburna. 
kemitsu, który przez resztę swojego życia utrzymywał trwałe przyjaźnie z pisarzami, malarzami, rzeźbiarzami czy reżyserami filmowymi i którego muzyka wydaje się właśnie wynikiem inspirujących spotkań z twórcami innych dziedzin sztuki. Muzycy skupieni w Warsztacie Eksperymentalnym wykazywali duże podobieństwo do współczesnych amerykańskich kompozytorów muzyki „eksperymentalnej", których sposób kompozycji był nieustannie wzbogacany o idee pochodzące z pozostałych obszarów sztuki. W tym samym czasie zachodnia sztuka awangardowa zaczynała zdobywać poparcie i uznanie środowisk akademickich, podczas gdy w Japonii traktowana była nadal jako wywrotowa alternatywa dla tradycji (Burt 40).

Aktywność Warsztatu Eksperymentalnego, przez sześć lat istnienia, przyjmowała różne formy. Pierwszym wydarzeniem kulturalnym zorganizowanym przez to stowarzyszenie była premiera baletu Ikiru yorokobi - Joie de vivre (Radość życia Joie de vivre), która odbyła się 16 listopada 1951 roku w sali koncertowej Hibiya Kōkaidō (Ratusz w Hibiya) w centrum Tokio. Takemitsu we współpracy z Suzukim skomponował muzykę baletu, a także dyrygował w czasie występu. Utwór ten był hołdem dla tak samo zatytułowanego (Joie de vivre, 1946) obrazu Pabla Picassa (1881-1973) (Orgins of Japanese media art- artist embracing technology from 1950's to early 1970's, http://isea2011.sabanciuniv.edu/paper/origins-japanesemedia-art-\%E2\%80\%93-artists-embracing-technology-1950s-early-1970s). Wybór baletu jako formy współpracy członków stowarzyszenia był nawiązaniem do baletów eksperymentalnych powstałych w Europie (jako reakcja na dadaizm i surrealizm) w latach dwudziestych oraz później na gruncie sceny awangardowej w Stanach Zjednoczonych. Obaj kompozytorzy dobitnie podkreślali również rolę wzajemnego odziaływania malarstwa, literatury i muzyki (Tezuka 64-85).

Wydarzeniem towarzyszącym premierze baletu była pierwsza w powojennej Japonii wystawa poświęcona malarstwu Pabla Picassa, zorganizowana przez redakcję gazety "Yomiuri Shinbun" ${ }^{8}$. Wykupienie wszystkich biletów może świadczyć o tym, że wśród publiczności pojawił się głód nowości. Zaprezentowany balet nie tylko odpowiadał na zainteresowanie sztuką niekonwencjonalną, ale przez nawiązanie do współczesnej sztuki Zachodu stał się też narzędziem walki z ksenofobią, która pojawiła się w powojennej Japonii (Tezuka 64-85). Sukces baletu i wystawy niewątpliwie zmotywował młodych artystów do dalszej pracy $\mathrm{w}$ duchu liberalizmu i eksperymentowania.

Kolejne eksploracje nowych środków wyrazu sztuki doprowadziły do realizacji wyjątkowych pomysłów. Było nim na przykład przedstawienie Ōto suraido

8 Wpływowa japońska gazeta działająca od 1872 roku, obecnie uznawana za gazetę o największym nakładzie na świecie. 
(Autoslajdy, 1953) polegające na pokazie nieruchomych obrazów wyświetlanych na ekranie w sposób skoordynowany z dźwiękiem nagranym na taśmie magnetofonowej. Efekt ten uzyskano za pomocą nowego projektora firmy Sony, którego konstrukcja umożliwiała synchronizację nagranego dźwięku z wyświetlanymi obrazami (Burt 40). Mimo że połączenie obrazu (slajdu) z dźwiękiem było rezultatem rozwinięcia idei muzyki konkretnej ${ }^{9}$, realizatorom chodziło raczej o stworzenie przede wszystkim zróżnicowanego widowiska multimedialnego z wykorzystaniem najnowszych technologii niż o zwykły muzyczny eksperyment.

Poza realizacją prekursorskich przedsięwzięć Warsztat Eksperymentalny zajmował się także organizacją typowych koncertów, których repertuar świadczył o pragnieniu zaznajamiania japońskiej publiczności z osiągnięciami muzyki zachodniej. Dzięki wysiłkom stowarzyszenia po raz pierwszy w kraju zaprezentowano utwory Oliviera Messiaena (1908-1992) i Arnolda Schönberga (1874-1951). Nie zabrakło również wykonań powstałych w tym czasie utworów Takemitsu, jak na przykład Distance de Fée (Dystans wróżki, 1951), zaprezentowany wcześniej na koncercie Szkoły Nowej Kompozycji (Burt 41).

Takemitsu, w okresie przynależności do Warsztatu Eksperymentalnego skomponował niewiele utworów (na przykład Relief Statique, Chamber Concerto). Można więc odnieść wrażenie, że nie był to znaczący okres w jego życiu zawodowym. Należy jednak pamiętać, że poza pisaniem tradycyjnych utworów instrumentalnych i koncertowaniem na scenie, kompozytor stale poszukiwał inspiracji i niekonwencjonalnych sposobów prezentowania muzyki. Pomysł tworzenia muzyki elektroakustycznej (w tym konkretnej) lub teatralnej przyszedł mu do głowy w latach pięćdziesiątych i znacznie później dowiedział się, że w 1948 roku uprzedził go już ktoś inny. Takemitsu pisze o tym następująco: „Francuski [inżynier] Pierre Schaeffer (1910-1995) wynalazł metodę muzyki konkretnej opartej na tej samej idei, co moja. Cieszyłem się z tego zbiegu okoliczności" (Fujii 63-67).

Zafascynowany możliwością wykorzystania dźwięków z naturalnego otoczenia, Takemitsu miał odmienny pogląd niż ten reprezentowany na Zachodzie. Podczas gdy Pierre Shaeffer pracował nad tym, by „oddzielić dźwięk od jego scenicznego kontekstu i podnieść go do godności muzycznego materiału" (Schaeffer 32), Takemitsu przeciwnie, zachęcał odbiorców do jego rozpoznawania (Burt 44). Oczywiście $\mathrm{w}$ jego utworach znajdziemy także dźwięki naturalne, które wprawdzie po specjalnej obróbce $\mathrm{w}$ studio stają się trudne do rozpoznania, ale ich użycie niewątpliwie prowadzi do nowych, interesujących rezultatów. Przykładowo w utworze Water Music (1960) odgłos spadających kropel wody brzmi jak trady-

${ }^{9}$ Muzyka konkretna (z franc. musique concrète) to kierunek w muzyce, w którym wykorzystuje się różne realne dźwięki (np. strumień wody, odgłosy przyrody) nagrane na taśmę, odpowiednio zmiksowane, włączane w utwór muzyczny. 
cyjne instrumenty perkusyjne $\mathrm{w}$ teatrze $n \bar{o}^{10}$. W muzyce do filmu Kaidan (Opowieści niesamowite, reż. Kobayashi Masaki, 1964) dźwięki na zmianę, to oderwane są od swojego pierwotnego, ilustracyjnego kontekstu (na przykład łamanie gałązek drewna stanowi tylko muzyczny materiał wkomponowany w utwór), to znowu okazują się muzyką fletu shakuhachi11 albo śpiewem aktora nō, skrytymi pod osłoną elektronicznej obróbki (przykładowo pozornie naturalne wycie wiatru podczas burzy śnieżnej czy huk fal oceanu).

Takemitsu szybko stracił zainteresowanie muzyką konkretną, jako formą umożliwiającą wykorzystywanie materiału nagranego na taśmie, ale przez resztę swojej kariery nie przestał jej komponować, podobnie jak muzyki akompaniującej utworom dramaturgicznym. Doświadczenia te w późniejszych latach zaowocowały z pewnością $\mathrm{w}$ taki sposób, że kompozytor z większą śmiałością posługiwał się surowymi barwami dźwięków naturalnych bez udziału instrumentów.

Do rozwoju współpracy Takemitsu z filmem przyczyniła niewątpliwie znajomość z kompozytorem Hayasaką Fumio (1914-1955), znanym najbardziej z muzyki do obrazów Mizoguchiego Kenjiego (1898-1956) czy Kurosawy Akiry (1910-1998). Takemitsu zdobył cenne doświadczenie, asystując Hayasakiemu. Dlatego na wiadomość o jego nagłej śmierci przeżył wielki wstrząs. Dwa lata później zmienił tytuł utworu Meditation na Requiem for strings i dedykował go swemu zmarłemu mentorowi. Z czasem okazało się, że właśnie to dzieło utorowało Takemitsu drogę do międzynarodowej kariery. Jej początek wyznacza niejako wykonanie monumentalnego Requiem przez Tokijską Orkiestrę Symfoniczną (Tōkyō Kōkyō Gakudan) Odtąd w twórczości Takemitsu zarysowuje się też nowy kierunek. Kompozytor będzie próbował realizować projekty bardziej ambitne i prestiżowe niż wcześniejsze kameralne kompozycje. W warstwie harmonicznej Requiem, tak jak w kolejnych utworach na przestrzeni kilku lat, nadal rozwija skale modalne Meassiena ${ }^{12}$. Rozszerzając swoje poszukiwania ciekawych środków harmonicznych, w naturalny sposób sięga do koncepcji ekspresjonistów Drugiej Szkoły Wiedeńskiej13, a w szczególności do Antona Weberna (1883-1945). W pierwszej z trzech części utworu Le son calligrafié (Wykaligrafowany dźwięk), w którym bardzo nieregularne figury rytmiczne budzą skojarzenia z estetyką ekspresjonizmu, Takemitsu dwukrotnie cytuje przebieg dwunastotonowej serii. Po raz pierwszy zabieg ten w klarowny sposób pojawia się na początku utworu, co można potraktować jako

10 Teatr $n \bar{o}$ - gatunek teatru japońskiego, zapoczątkowanego w XIV wieku, skupiającego w sobie śpiew, taniec oraz powściągliwą muzykę przede wszystkim instrumentów perkusyjnych.

11 Shakuhachi - japoński flet prosty wykonany z drewna bambusowego.

12 Ustalone siedem skal, złożone z następstw interwałów powtarzanych kilka (dwa lub trzy razy), tworzące podstawę charakterystycznej harmonii i melodii w utworach Messieana.

${ }^{13}$ Druga Szkoła Wiedeńska (Zweite Wiener Schule) - grupa kompozytorów tworzących w latach dwudziestych i trzydziestych XX wieku w Wiedniu, kojarzonych z ekspresjonizmem czy techniką dodekafoniczną, reprezentowana przede wszystkim przez A. Schönberga (1874-1951), A. Weberna i A. Berga (1885-1935). 
zwiastun nowej w dorobku Takemitsu "dwunastotonowej” kompozycji, jednakże $\mathrm{w}$ następnych taktach kompozytor nie kontynuuje koncepcji serializmu ${ }^{14}$ i posiłkuje się znanymi już z wcześniejszych dzieł zastosowaniami modusów Maessiena. Tego rodzaju niekonsekwencja stała się powodem często przesadnej krytyki.

Zwrócono natomiast uwagę, że tytuł Wykaligrafowany dźwięk nawiązuje do japońskiej sztuki kaligrafii, co - jak komentowano - mogło oznaczać, iż Takemitsu zaczynał zmieniać swój negatywny stosunek do rodzimej tradycji i dostrzegać w niej wartości, na które wcześniej nie zwracał uwagi (Burt 62).

\section{Przełom w karierze}

Zainteresowanie Takemitsu i innych japońskich kompozytorów muzyką europejską spotkało się z wzajemnością. W 1958 roku na przykład Igor Strawiński (1882-1971) podczas wizyty w Japonii poprosił stację telewizyjną NHK ${ }^{15}$ o zaprezentowanie mu kilku najnowszych nagrań muzyki japońskiej. To niejako przypadek sprawił, że chociaż nie było to zaplanowane, podczas audycji puszczono początek Requiem Takemitsu. Realizatorzy programu chcieli przerwać utwór, lecz Strawiński powstrzymał ich, ponieważ pragnął wysłuchać go do końca. Później podczas konferencji prasowej, kiedy został zapytany o to, które z usłyszanych kompozycji uważa za godne uwagi, Strawiński wymienił tylko nazwisko Takemitsu, a następnie zaprosił go na obiad (Burt 71).

Wydarzenie to, przez Takemitsu określone jako „niezapomniane”, bezapelacyjnie odmieniło los japońskiego kompozytora. Dzięki Strawińskiemu jego muzyka stawała się coraz lepiej rozumiana i popularniejsza i w Japonii, i na świecie. Wkrótce po powrocie Rosjanina do Stanów Zjednoczonych Takemitsu otrzymał zamówienie z Fundacji Kusewickiego ${ }^{16}$. Skomponował wówczas The Dorian Horizon (1966) - utwór, który przyniósł mu pieniądze i nieprzemijającą do dziś międzynarodową sławę (Burt 71).

\section{Publikacje Takemitsu - muzyka zachodnia a muzyka japońska}

W rozumieniu muzyki Takemitsu niezwykle pomocne są komentarze kompozytora do własnych kompozycji. W eseju z 1974 roku Ki no kagami, sōgen no kagami

\footnotetext{
14 Serializm - nurt w muzyce współczesnej, którego technika kompozytorska polegała na podporządkowaniu wysokości dźwięku, rytmu i innych elementów w szeregi zwane seriami, które w trakcie utworu poddawane są rozmaitym przekształceniom.

${ }^{15}$ NHK (jap. Nippon Hōsō Kyōkai) - japońska państwowa stacja radiowo-telewizyjna.

${ }^{16}$ Fundacja Kusewickiego (Kussevitzky Music Foundations) - fundacja założona przez kompozytora Sergieja Kusewickiego (1874-1951) w 1942 roku wspierającą młodych kompozytorów np. przez zlecanie im pisania nowych utworów, a później pokrywanie kosztów ich prezentacji.
} 
(Lustro drzewa, lustro trawy) znajdujemy potwierdzenie, że z wyjątkiem sporadycznych przypadków Takemitsu czerpał inspirację wyłącznie z muzyki zachodniej, którą porównywał do drzewa. Takemitsu, dokonując porównania zachodniej sceny muzycznej do drzewa, zwracał uwagę na istnienie w niej silnych, w pełni ukształtowanych, indywidualnych jednostek, obok których muzyka Wschodu „wyrasta jako trawa” (Burt 73). Takemitsu przyznawał się do tego, że zachodnia muzyka stała się dla niego głównym źródłem inspiracji, ponieważ wydawała mu się bardziej atrakcyjna: „Kiedyś wierzyłem, że aby tworzyć muzykę, muszę zobaczyć się w tym ogromnym lustrze nazwanym Zachodem." (Takemitsu 1992: 46).

Zanim jednak utwory Takemitsu nabiorą zdecydowanie oryginalnych cech, odbicie „zachodniego lustra” pozostaje w nich niezmiennie wyraźne. Artysta właśnie w tym okresie osobiście poznał wielu światowej sławy kompozytorów i z coraz większą świadomością poddawał się ich wpływowi (Burt 73). Jego utwory stały się dojrzalsze i stylem przypominające dzieła zachodnich muzyków awangardowych. Można zaryzykować stwierdzenie, że bez znajomości poznanych dzięki temu powstałych na Zachodzie technik, adaptacja wschodniej muzyki, w sposób, w jaki robił to Takemitsu, nie byłaby możliwa.

\section{Serializm}

Dokładna analiza utworów Takemitsu po raz kolejny naprowadza na ślad serializmu. Fragmenty skomponowane w oparciu o zasady serializmu odnajdziemy w utworach takich, jak: Ki no kyoku (Utwór drzewa, 1961), Ring (Okrąg, 1961), Sacrifice (1962), Hika (Pieśń żałobna, 1966). Mimo to we wszystkich tych utworach partie $\mathrm{w}$ technice dwunastotonowej są - można powiedzieć - skromne i obecne w śladowych ilościach, nie stanowią zatem żadnej konsekwentnie przestrzeganej zasady unifikującej całe kompozycje. Takemitsu nie zgłębia dokładnie metod serializmu, a jedynie w sposób powierzchowny sygnalizuje swoje zainteresowanie, skupiając więcej uwagi na technikach kontrapunktycznych. Nie świadczy to jednak o nieudolności czy ograniczeniach, lecz o określonym wyborze kompozytora. Scepcytyzm w stosunku do takich sztucznych rozwiązań, jak na przykład serializm, znajduje uzasadnienie $\mathrm{w}$ preferencjach estetycznych kompozytora, który przedkładał wartość barwy i dźwięku nad technikę (Burt 79).

\section{Wpływ Johna Cage'a - powrót do tradycji}

Bardzo duże znaczenie na kształtowanie się stylu Takemitsu miał John Cage (1912-1992) wprawiający w zdumienie cały zachodni świat muzyczny. Swoimi ekstrawaganckimi realizacjami "głęboko poruszył" Takemitsu. Szczególnie silne 
wrażenie zrobił na nim Koncert na fortepian i orkiestre (Concert for Piano and Orchestra) Cage'a, który usłyszał w 1961 roku w ramach IV Festiwalu Muzyki Wspólczesnej w Osace (Ōsaka Dai Yonkai Ongakusai), w wykonaniu Ichiyanagiego Toshiego (ur. 1933) - japońskiego pianisty studiującego wcześniej dziewięć lat w Stanach Zjednoczonych. Nawet trzydzieści jeden lat później, po śmierci Cage'a, Takemitsu napisze: „Wciąż czuję ten szok po wysłuchaniu tego utworu” (Burt 92).

Inspiracja amerykańskim kompozytorem jest dwukierunkowa, ponieważ z jednej strony Takemitsu czyni z jego dzieła ważne źródło własnej inspiracji, zapoznaje z nim Japończyków, ale przede wszystkim, paradoksalnie, pod wpływem Cage'a kieruje swoją uwagę $\mathrm{w}$ stronę japońskiego muzycznego dziedzictwa narodowego.

Początkowo Takemitsu wykorzystywał najbardziej znany wynalazek Cage'a fortepian preparowany, czyli fortepian o nietypowym brzmieniu, osiąganym dzięki wkładaniu do wnętrza instrumentu różnorodnych przedmiotów. Instrument taki można usłyszeć $\mathrm{w}$ muzyce filmowej Takemitsu $\mathrm{z}$ lat sześćdziesiątych XX wieku. Kompozytor był wówczas przekonany o konieczności poszukiwania nowej barwy instrumentów, aby muzyka filmowa współgrała z nową jakością rozwijającego się kina.

Reżyserzy próbowali kręcić filmy w nowy sposób. [...] Dlatego kompozytorzy automatycznie chcieli eksperymentować z muzyką tak samo jak reżyserzy z filmem. To, co jest najważniejsze, to ustawienie dźwięku. To właśnie sam dźwięk zostawia największe wrażenie. (Music for the Movies: Tōru Takemitsu. Reż. Charlotte Zwerin. Perf. Tōru Takemitsu. Sony BMG USA 1994. DVD)

Powszechnie podkreślano zainteresowanie Cage'a kulturą japońską, którą, jak sam zaznaczał, uczynił on fundamentem swojej muzyki. To niewątpliwie wywarło przemożny wpływ na zmianę antyjapońskiego nastawienia przez Takemitsu. Cage nie był oczywiście pierwszym zachodnim twórcą zafascynowanym Japonią, jednakże jego wiedza o tym kraju była gruntowna, więc potrafił nie tylko naśladować muzyczny styl tradycyjnej japońskiej muzyki, ale również wykorzystywać we własnych kompozycjach elementów japońskiej myśli filozoficznej zen. Takemitsu natomiast tak oto opisuje swój związek z twórczością Cage'a:

Japończycy, którzy byli pod wpływem Zachodu i twórcy z Zachodu zainspirowani kulturą Wschodu spotkali się $\mathrm{w}$ tym samym miejscu. Stoją obecnie w tym samym punkcie, do którego dotarli z przeciwnych kierunków. Według mnie droga Johna Cage'a jest bardzo logiczna, podczas gdy inspiracja Japończyków Zachodem była, moim zdaniem, bardziej płynna i brakowało jej takiej logiki. Pomimo to muszę przynajmniej podziękować Johnowi Cage'owi. Do pewnego czasu uważałem Japonię za coś, co powinno się odrzucać, ale dzięki niemu zwróciłem uwagę na pozytywne strony rodzimej tradycji. 
[...] John Cage był pod dużym wpływem zen i Suzukiego Daisetsu17. [...] Zgadzamy się teraz, że z punktu widzenia wzajemnej wymiany nie ma znaczenia dyskusja o tym, która ze stron wpłynęła na drugą pierwsza. (Takemitsu 1996: 26)

Cage, całkowicie oddany tworzeniu muzyki, zadawał sobie takie pytania, jak: „Czym przede wszystkim jest muzyka? Jaka jest różnica między dźwiękiem a odgłosem? Czym jest cisza?" (Sakamoto 1). Odpowiedzi znajdował w myśli filozoficznej zen, której fundamentalnym elementem jest idea jednoczesnego bytu i niebytu wszystkich rzeczy. To zestawienie dwóch - jak by się mogło wydawać sprzeczności ukształtowało unikalny styl muzyczny Cage'a oraz ukierunkowało jego sposób postrzegania muzyki i ciszy. W porównaniu do serializmu czy techniki dodekafonicznej ${ }^{18}$ prostota koncepcji ciszy oraz muzyki aleatorycznej, a zarazem jej zgodność z japońską kulturą, była dla większości Japończyków tak zaskakująca, że reakcję na muzykę Cage'a określa się mianem "Cage'owskiego szoku” (Sakamoto 20). Takemitsu im lepiej poznawał leżącą u podstaw muzyki Cage'a filozofię zen, tym bardziej był do niej przekonany i w swoich kompozycjach snuł rozważania na temat ogólnej roli muzyki, a w niej dźwięku i ciszy, i coraz mniej interesowały go skomplikowane techniki. W spojrzeniu obu kompozytorów na muzykę widoczne są jednak różnice. Takemitsu nigdy nie zgodził się z opinią Cage'a, że muzyka jest rzeczą niezamierzoną, a dźwięki są tylko dźwiękami, nie zaś środkiem wyrazu ludzkich emocji czy osobistych teorii (Burt 97). Zaczął on pojmować muzykę jako naturalny, spontaniczny wyraz emocji. Emocjonalny i osobisty charakter jego utworów, zwłaszcza w późniejszych latach twórczości, nie jest zatem zgodny $\mathrm{z}$ brakiem intencji komponowania $\mathrm{w}$ duchu zen.

Zainteresowanie Takemitsu rodzimą kulturą zrodziło się jeszcze wcześniej, bo w roku 1958, bezpośrednio po obejrzeniu przedstawienia teatru lalkowego bunra$k u^{19}$. Kompozytor przyznał, że został oczarowany przez tradycyjne instrumenty towarzyszące przedstawieniu, w szczególności trójstrunowego futozao, czyli większą odmianą shamisenu ${ }^{20}$ : "Świat dźwięku stworzonego przez futozao nie był mniej imponujący niż świat zachodniej orkiestry z setką różnych instrumentów. Być może dla mnie jest on nawet bogatszy" (Takemitsu 1995: 53).

W muzyce filmowej, którą stworzył w latach sześćdziesiątych pobrzmiewają japońskie instrumenty. Po latach, w 1994 roku, kompozytor przyznał w wywia-

17 Suzuki Daisetsu (1870-1966) - japoński profesor filozofii buddyjskiej, popularyzator zen na Zachodzie.

${ }^{18}$ Dodekafonia - technika kompozytorska w muzyce współczesnej, odrzucająca tonalność, traktująca każdy dźwięk dwunastotonowej skali równoważnie.

${ }^{19}$ Bunraku - japoński tradycyjny teatr lalkowy.

20 Shamisen - trzystrunowy instrument szarpany o kształcie podobnym do współczesnej gitary jednak o wiele cieńszym, bezprogowym gryfie i mniejszym, nieco kwadratowym pudle rezonansowym. 
dzie, że świadomie wykorzystywał lutnię biwa21, shamisen czy flet shakuhachi (Music for the Movies: Tōru Takemitsu. Reż. Charlotte Zwerin. Perf. Tōru Takemitsu. Sony BMG USA 1994. DVD).

Wyznaniem tym Takemitsu, który wcześniej niejako wyrzekał się kultury japońskiej i pieczołowicie dbał o to, by jego utwory były pozbawione jakichkolwiek narodowych elementów, zaskoczył wszystkich. Należy jednak pamiętać, że słowa te zostały wypowiedziane z perspektywy czasu i dotyczyły okresu, w którym nastąpił wyraźny przełom $\mathrm{w}$ twórczości kompozytora, a wypracowany przez niego unikalny, bez trudu rozpoznawalny styl, zaczął ułatwiać - na całym świecie promocję filmów z jego muzyką (Music for the Movies: Tōru Takemitsu. Reż. Charlotte Zwerin. Perf. Tōru Takemitsu. Sony BMG USA 1994. DVD).

Od tamtej pory Takemitsu zajmował się również komponowaniem utworów na tradycyjne instrumenty japońskie. W 1966 roku stworzył Eclipse (Zaćmienie) na lutnię biwa i flet shakuhachi, którymi najbardziej się zainteresował. Kiedy nagranie tego utworu usłyszał amerykański dyrygent i kompozytor Leonard Bernstein (1918-1990), był pod tak pod dużym wrażeniem, że poprosił Takemitsu o napisanie utworu na orkiestrę, biwa i shakuhachi dla Nowojorskiej Filharmonii z okazji sto dwudziestej piątej rocznicy jej powstania (Burt 111). Tak doszło do skomponowania November Steps (Listopadowe kroki, 1967), które przyniosły Takemitsu międzynarodową sławę i sprawiły, że odtąd jego znakiem charakterystycznym stała się muzyka łącząca w sobie elementy tradycji zachodniej i wschodniej. Takemitsu zawsze podkreślał, że w November Steps delikatność japońskich instrumentów wyraźnie kontrastuje $\mathrm{z}$ gęstą fakturą zachodniej orkiestry. Zwracał też uwagę na to, że takie połączenie odległych sobie tradycji muzycznych wydawało mu się właściwe jedynie na zasadzie wyraźnego przeciwieństwa, nie zaś scalenia (Robinson 39). Taka innowacyjna instrumentacja spotkała się $\mathrm{z}$ wielkim uznaniem na całym świecie, a dodatkowo przyczyniła się do rozpowszechnienia oryginalnej japońskiej muzyki.

Wraz z powstaniem November Steps, a potem utworu Green (1967) pierwotnie zatytułowanego November Steps II Takemitsu stracił zainteresowanie Drugą Szkołą Wiedeńską. W latach siedemdziesiątych jego twórczość będzie już naznaczona fascynacją impresjonizmem Debussy'ego, przejawiającą się przede wszystkim $\mathrm{w}$ bardzo wyraźnych podobieństwach do języka harmonicznego dzieł orkiestrowych francuskiego kompozytora. Ten okres w karierze Takemitsu bywa niekiedy określany okresem Debussy'ego (Burt 14).

Nietypową instrumentację, podobną do tych używanych przez Debussy'ego, Takemitsu często wykorzystywał w wielu późniejszych utworach. Na przykład instrumentację, zaczerpniętą z Sonaty na flet, altówkę i harfę (1915) Debussy'ego, odnajdziemy w trio And I knew'twas Wind (1992). W innych kompozycjach Take-

${ }^{21}$ Biwa - rodzaj lutni japońskiej o czterech strunach szarpanych drewnianym plektronem. 
mitsu uwagę zwraca ponadto brak stałego metrum. W zamian pojawiają się w nich zróżnicowane, przeplatające się metra, które zakłócają poczucie regularności rytmu (Robinson 24). Z czasem typowe dla dzieł Debussy'ego modyfikacje metryczne stały się powszechnie stosowane przez wielu innych kompozytorów XX wieku.

\section{Serie tematyczne}

Analiza utworów Takemitsu powstałych w latach siedemdziesiątych umożliwia prześledzenie ewolucji stylu tego kompozytora. W dziełach z tego okresu wyraźnie została uwypuklona partia najwyższego rejestru. Wiele $\mathrm{z}$ nich nadal koresponduje z kompozycjami europejskimi - czy to w warstwie muzycznej (użycie charakterystycznych motywów, języka harmonicznego, instrumentów), czy choćby poprzez dedykowanie ich zachodnim twórcom. Dla stylistyki tych utworów typowe są jednak uproszczenia strony technicznej i wyeksponowanie warstwy melodycznej.

Zmiany bez trudu zauważali i komentowali krytycy. Na przykład Allen Hughes w recenzji dla New York Times utworu Quatrain (Czterowiersz, 1975), którego instrumentacja (klarnet, skrzypce, wiolonczela i fortepian) wzorowana była na słynnym Kwartecie na koniec czasów Messiaena, stwierdza: "Quatrain jest tak ładny, tak okazały i emanujący bogactwem melodii, żywymi kolorami oraz szerokim spektrum dźwiękowym, że aż trudno w to uwierzyć" (Hughes 25).

Hughes słusznie przeczuwał, że zarówno w stylu Takemitsu, jak i w światowej muzyce zajdą ważne zmiany. Japoński twórca porzucił awangardowy język muzyczny i - tak jak widoczne jest to w dziełach wielu innych kompozytorów skoncentrował się na bardziej tonalnej melodyce, uproszczonej strukturze oraz ekspresji wynikającej z barwy instrumentów, eksponując dzięki temu jednocześnie cechy estetyki japońskiej.

Cyklem utworów In an Autumn Garden (1973-1979), Garden Rain (1974) i A Flock Descends into the Pentagonal Garden (1977) Takemitsu zwraca uwagę Zachodu na wyjątkowość japońskich ogrodów zen. Kompozycję In an Autumn Garden napisał dla japońskiego Teatru Narodowego (Kokuritsu Gekijō), którego dyrekcja w 1970 roku postanowiła zlecić współczesnym kompozytorom japońskim i zagranicznym napisanie utworów dla Cesarskiego Zespołu Gagaku (Kunaichō Gagakubu). Premiera odbyła się 30 października 1973 roku, ale w ciągu kolejnych sześciu lat Takemitsu dopisał pięć dodatkowych części. W ten sposób stworzył Shuteiga Ichigu (Jesienny ogród - kompletna wersja, 1979), który, choć - zgodnie z założeniem - miał być wykonany przez muzyków reprezentujących najbardziej tradycyjny nurt muzyki japońskiej, to jednak w utworze tym to, co rdzennie japońskie zostało celowo zmieszane $\mathrm{z}$ elementami tradycyjnej muzyki zachodniej. Tytuły części pierwszej i ostatniej utworu, Strophe i Antistrophe, a także użyte skale melo- 
dyczne, mimo że wykazują podobieństwo do skal typowych dla gagaku22, nawiązują raczej do muzyki starożytnej Grecji. Nie oznacza to, że Takemitsu nie zastosował w swoim utworze ortodoksyjnych praktyk wykonawczych orkiestry gagaku. Partie bębna $k a k k o^{23}$ czy cytry koto zawierają takie same, równoczesne figury rytmiczne jak w tradycyjnej muzyce gagaku. Jej charakterystyczną cechą są także niezależne wariacje tej samej melodii, zwane heterofonią, z której kompozytor nie zrezygnował w Shuteiga - Ichigu (Burst 164). Natomiast w powstałej w tym samym okresie serii utworów, podobnie jak we wcześniejszej kompozycji Arc for orchestra and piano (1965) zaznaczył swoje zainteresowanie japońskimi ogrodami zen (Burt 166).

Utwór Garden Rain, oprócz wykorzystania motywu ogrodu, otwiera również nową serię o pozamuzycznych powiązaniach, która rozwijana była przez Takemitsu przez wiele lat. Tematem przewodnim dzieł powstałych $\mathrm{w}$ latach osiemdziesiątych staje się woda. Scala je konkretny motyw melodyczny złożony z dźwięków Es, E, A, które po polsku i po niemiecku odczytuje się tak samo, jak brzmi przeliterowane angielskie słowo „morze” (,s-e-a"). Melodię złożoną z tych konkretnych dźwięków, jej transponowaną wersję lub liczne wariacje można odnaleźć w niemalże wszystkich utworach Takemitsu powstałych w ciągu lat siedemdziesiątych i osiemdziesiątych. Są wśród nich na przykład: Quatrain, Toward the Sea (Ku morzu, 1981), A Way a Lone (1981), Rain Tree (1981), Dreamtime (1981), Rain Tree Sketch (1982), Rain Coming (1982), I Hear the Water Dreaming (1987), Rain Spell (1982) i inne. Taka metoda kompozycyjna staje się znakiem wyróżniającym styl Takemitsu, wyraźnie odzwierciedlająca jego fascynację motywem wody. Pod względem technicznym dzieła te są świadectwem dalszego odchodzenia od faktury awangardowej i uproszczenia warstwy harmonicznej. Nowemu kierunkowi, w którym zaczął podążać, Takemitsu nadał metaforyczną nazwę "morze tonalności". Wielokrotne użycie (tak interpretowanego) melodycznego motywu "morza”, w okresie, gdy zainteresowanie kompozytora tonalnością stawało się coraz bardziej wyraźne, wydaje się w pełni uzasadnione (Burt 177).

Dbałość o barwę w muzyce, charakterystyczna dla tego okresu twórczości Takemitsu, przejawia się nie tyle $\mathrm{w}$ wykorzystaniu nietypowych instrumentacji, ile $\mathrm{w}$ odnajdowaniu nowych możliwości $\mathrm{w}$ technice gry, polegających na uwzględnianiu konwencjonalnych, europejskich aparatów muzycznych. Na przykład $\mathrm{w}$ utworze na flet altowy Towards the Sea kompozytor umieszcza wielotonowe tryle, a w Rain Spell nakazuje nastrojenie w ćwierćtonach pięciu strun harfy, co

22 Gagaku - japońska klasyczna muzyka dworska, której tradycyjne instrumentarium składa się z instrumentów dętych ryūteki, hichiriki, shō, japońskich instrumentów perkusyjnych oraz lutni biwa i cytry koto. Muzyka charakteryzuje się m.in. wolnym tempem, wahaniami metrycznymi oraz oparciem o skale pentatoniczne.

${ }^{23}$ Kakko - rodzaj japońskiego bębna z membraną z obydwu stron. Jest mniejszy od podobnego, bardziej znanego bębna taiko i różni się od niego sposobem naciągnięcia membrany. Wykorzystywany w muzyce dworskiej gagaku. 
przy wykonywaniu glissanda nadaje mu orientalne brzmienie. $\mathrm{W}$ tamtych czasach takie rozwiązanie było dla zachodnich słuchaczy jeszcze bardziej interesujące (Burt 189). Szczególny koloryt natomiast w zamyśle kompozytora ma zostać wydobyty dzięki odpowiedniemu gospodarowaniu czasem $w$ muzyce i stworzeniu poczucia rozległej przestrzeni, które kompozytor określa za pomocą ma (przestrzeń, przerwa, interwał, cisza), czyli tradycyjnej, japońskiej kategorii estetycznej. Znaczenie wplecionego w filozofię zen pojęcia ma dla muzyki Takemitsu zostanie wyjaśnione $\mathrm{w}$ dalszej kolejności, jednak $\mathrm{w}$ tym miejscu warto wspomnieć, że operowanie ciszą (czy muzyczną przestrzenią) stało się w niektórych jego utworach tak szerokie, iż może być traktowane jako główny motyw konstruujący całe dzieła.

Z czasem Takemitsu coraz częściej tworzył utwory wyraźnie przewijającym się $\mathrm{w}$ nich motywem przewodnim. W wielu utworach zawrze odniesienia nie tylko do muzyki innych kompozytorów, ale również do literatury. Na przykład w Rain Tree, przemyślanej ilustracji fragmentu powieści japońskiego noblisty (1994) Ōe Kenzaburō (ur. 1935) pt. Atama no ii „ame no ki" (Inteligentne „deszczowe drzewo”, 1982), Takemitsu osiągnął niejako teatralny efekt bez angażowania aktorów. Uzyskał to za pomocą skierowanych na trzech perkusyjnych solistów świateł, które są włączane i wyłączane w odpowiednich momentach utworu. Spektakl świateł i perkusyjnych dźwięków oddaje obraz hawajskiego drzewa skąpanego w kroplach deszczu, opisanego przez Ōe w powieści. Utwory takie jak Rain Tree, jakby teatralizowane, są również postrzegane jako typowe dla Takemitsu (Burt 189).

Programowe treści muzyki Takemitsu, oprócz morza czy ogrodu, dotyczą również motywów gwiazd czy snu. Kompozycje na gitarę i orkiestrę To the Edge of Dream (1983) powstały z inspiracji onirycznymi obrazami belgijskiego malarza Paula Delvaux (1897-1994) (Burt 190). Połączenie tropu „wody" i "snu” w Rain Dreaming i Water Dreaming nie jest jednak oryginalnym pomysłem Takemitsu. Musiał on zapewne zauważyć, że zestawienie takie pojawia się w tytule eseju francuskiego pisarza Gastona Bachelarda (1884-1962) L'Eau et les rêves (Woda i sny, 1942), którego twórczością Takemitsu był zachwycony. Powszechnie wiadomo też o fascynacji kompozytora dziełami Jamesa Joyce'a (1882-1941), w którego ostatniej powieści Finneganów tren (1939) napotkamy zarówno na narrację oddającą nastrój snu, jak i na motyw wody.

\section{Ostatnie lata kariery}

Z czasem ujawnianie źródeł inspiracji, informacji o świadomym wykorzystaniu jakichś symboli czy motywów literackich, a także dedykowanie poszczególnych utworów konkretnym osobom stało się stałym zwyczajem Takemitsu. Komponowanie muzyki było jego formą wyrażania uznania dla dokonań innych artystów oraz snucia refleksji na temat otaczającego świata. Muzyka Takemitsu wy- 
pływała z przeżywanych przez niego emocji, z potrzeby serca. $Z$ tego powodu zdecydowanie odróżnia się od twórczości kompozytorów o analitycznym, matematycznym umyśle i może być nazywana romantyczną. Zjednywał sobie słuchaczy stylem świadczącym o oryginalnej wyobraźni muzycznej i o wielkiej wrażliwości. Na początku lat dziewięćdziesiątych zaczęto go jednak posądzać o to, że przestał się liczyć ze zdaniem krytyków i pozwolił sobie na pisanie muzyki romantyczno-ekspresjonistycznej czy wręcz sentymentalnej (Burt 217).

Takemitsu kontynuuje eksploracje w „morzu tonalności” i coraz częściej używa klasycznych zakończeń harmonicznych. Oprócz ma i sawari24 szczególną wagę przywiązuje do melodii, co wprawdzie nie jest nowością $w$ jego twórczości, ale dzięki temu jego muzyka wymyka się poza obowiązujące wówczas trendy. Już w 1975 roku Takemitsu miał powiedzieć o sobie: „Chyba jestem staromodny, bo należę do 'kompozytorów piosenek', którzy przywiązują wagę do [wzorowanej na śpiewie] melodii" (Takemitsu 1992: 63). Pod koniec życia jeszcze bardziej umocnił się w tym przekonaniu. W ostatnim ukończonym dziele Air (Powietrze/Aria, 1995) na flet solo, Takemitsu, choć wydawać by się mogło, że odnosi się do oddechu wykonawcy, w tytule nawiązuje do starego angielskiego słowa oznaczającego arię. Aluzję do śpiewu kompozytor ukrywa również w tytułach Fantasma/Cantos (1991) czy Spectral Canticle (1995). W jednym z ostatnich wywiadów, udzielnym pianistce Ogawa Noriko dla BBC, Takemitsu wyraził swój żal z powodu współczesnej tendencji do umniejszania znaczenia śpiewnych melodii $\mathrm{w}$ muzyce klasycznej (Burt 217).

To upodobanie tonalności i melodyjności nasuwa skojarzenie z mniej „poważną" twórczością Takemitsu - z muzyką filmową i aranżacjami popowych piosenek. W rzeczywistości spowodował, że bardziej rozrywkowe formy muzyczne przestały być traktowane $\mathrm{z}$ mniejszą powagą niż klasyczna muzyka koncertowa. Japoński kompozytor uznając, że są w równym stopniu wartościowe, zatarł granice między nimi. Kiedy dwadzieścia pięć lat po prawykonaniu November Steps przez Nowojorską Filharmonię, Takemitsu został ponownie poproszony o skomponowanie utworu okolicznościowego, tym razem mającego uświetnić obchody sto pięćdziesiątej rocznicy istnienia tej orkiestry, Takemitsu napisał Family Tree - Musical Verses for Young People (1992) na orkiestrę i narratora. Lekkie melodie smyczków i funkcyjnych akompaniamentów sprawiły, że nikt nie mógł oprzeć się wrażeniu, iż słucha raczej muzyki filmowej niż kompozycji na miarę festiwali muzyki współczesnej (Burt 217). To - zdawałoby się - powierzchowne wrażenie okazało się jednak trafne, ponieważ Takemitsu niemal dosłownie zacytował melodie z muzyki do filmu Night on Earth (Noc na Ziemi, 1991) Jima Jarmuscha (ur. 1953), której użycia reżyser odmówił (Burt 217). Takemitsu wprowadził do swojej nowej kompozycji fragmenty innych własnych lub cudzych utworów, a wszelkie zarzuty dotyczące

${ }^{24}$ Zostanie wyjaśnione w dalszej kolejności. 
tej kwestii skomentował z właściwą sobie inteligencją i skłonnością do posługiwania się metaforą, przywołując obraz ogrodu, w którym znajdują przyjazne miejsce wszystkie sprowadzone do niego z zewnątrz rośliny i przedmioty (Burt 220).

Odrębną grupę utworów Takemitsu stanowią muzyczne epitafia dla wybitnych artystów. Są wśród nich utwory poświęcone pamięci dwóch najbardziej cenionych przez niego kompozytorów - zmarłych w 1992 roku Johna Cage'a oraz Oliviera Messiaen. Dla tego ostatniego Takemitsu napisał Rain Tree Sketch II (1992) na fortepian (Burt 231).

W twórczości dedykowanej zmarłym kompozytorom odnajdziemy także polski akcent. W 1994 roku Takemitsu stworzył Paths (1994) - epitafium dla Witolda Lutosławskiego (1913-1994), wykonane w tym samym roku na Festiwalu Muzyki Współczesnej Warszawska Jesień. Utwór ten był ostatnim tombeau Takemitsu. Dwa lata później sam podupadł na zdrowiu. Walczył z rakiem i zapaleniem płuc. Zmarł w 1996 w Tokio. Jego Requiem (1957), dedykowane swojemu mentorowi, kompozytorowi Hayasace Fumio, zostało potraktowane jako msza żałobna również dla niego samego (Burt 232).

\section{Estetyka japońska w muzyce Takemitsu}

Takemitsu, odkrywając na nowo swoją japońską tożsamość, zaczyna się odwoływać do tradycyjnych kategorii estetyki japońskiej. Pojęcia sawari i ma, a także symbolika japońskich ogrodów zen mają wyjątkowe znaczenie dla stylu jego utworów i ich pojmowania. To te kategorie determinują rolę ciszy, barwy dźwięku w muzyce Takemitsu czy jej związek z naturą. Kompozytor, omawiając własne utwory, niejednokrotnie podkreślał ich istotę oraz odmienne od europejskiego filozoficzne przesłanie. Ślady większości jego koncepcji można też odnaleźć w twórczości Cage'a.

\section{Sawari}

Ważną dla Takemitsu tradycyjną kategorią estetyczną było sawari. Słowo to oznacza dotknięcie, czucie, przeszkodę, ale w terminologii muzycznej odnosi się do ostrego, pojedynczego dźwięku charakterystycznego dla tradycyjnej muzyki japońskiej. Ten perkusyjny, brzęczący dźwięk wydobywa się w momencie gry na instrumentach strunowych, takich jak lutnia biwa czy shamisen, kiedy plektron ${ }^{25}$, po szarpnięciu struny, uderza o pudło rezonansowe (Sakata 141-152).

Sawari jest sprzeczne z estetyką dźwięku w tradycyjnej muzyce zachodniej, w której obowiązywała troska o zachowanie barwy czystej i niczym niezakłóconej

${ }_{25}$ Plektron - przyrząd do gry na niektórych instrumentach strunowych potocznie zwany „piórkiem” lub „kostką"; to nim, zamiast palcami, szarpie się i uderza struny lub pudło rezonansowe. 
melodii danego instrumentu. Zamierzonym efektem końcowym kompozycji ma być skonstruowanie złożonej całości, co możliwe jest tylko dzięki nieskazitelności barwy poszczególnych dźwięków. Japońskie skojarzenia z pojęciem dobrego, pięknego dźwięku są inne. Idealna gra instrumentu barwą przypomina odgłosy natury, w stosunku do której Japończycy zawsze mieli poddańczy stosunek. Dlatego również w przypadku fletu shakuhachi doskonałe byłoby uzyskanie brzmienia podobnego do wiatru wiejącego $\mathrm{w}$ gaju bambusowym, a na shamisenie dźwięk najwyższej próby, czyli sawari, powinien przypominać odgłos cykady (Sakamoto 28).

Według Takemitsu istotą japońskiej muzyki jest jej integracja z naturą i traktowanie pojedynczego dźwięku jako pełnowartościowego. Większość zachodnich twórców preferuje natomiast dźwięki odróżniające się od odgłosów natury i stanowiące jedynie tworzywo potrzebne do zbudowania większej całości (Takemitsu 1975: 150-152).

Dźwięki - zdaniem Takemitsu - rozchodzą się poprzez artystę, potem zlewają się z naturą, by objawić się raczej jako obecność niż istnienie. W procesie ich tworzenia zniszczone zostaje myślenie teoretyczne. Pojedynczy brzdęk strun lub nawet szarpnięcie jest zbyt złożone, zbyt kompletne samo w sobie, by to teoretyzować. (Takemitsu 1995: 51)

Inaczej niż na Zachodzie indywidualne dźwięki stanowią same w sobie kompleksowe wydarzenie i nie obligują kompozytora do tworzenia związków między nimi. To w dużym stopniu podnosi znaczenie ich barwy. Samodzielność dźwięków implikuje niemożność przypisania ich do konkretnej skali czy systemu harmonicznego, co Takemitsu uznawał za walor:

Ze względu na to, że nuta istnieje również w izolacji, znaczenie skali, do której przynależy staje się mniej ważne. Dźwięk przybliża się zatem do warunków przypominających ciszę, ponieważ nie odróżnia się od naturalnych odgłosów, które, choć pełne są konkretnych tonów, jako całość reprezentują ciszę ma. (Takemitsu 1975: 20)

Sawari jako dźwięk, który zbliżony jest do zwykłego, "niemuzycznego” odgłosu, ilustruje - jak to określał Takemitsu - strumień dźwięku (jap. oto no kawa). Kompozytor uważał, że muzyka powstaje właśnie ze strumienia dźwięku, czyli z odgłosów otaczających nas w życiu codziennym (Sakamoto 38). Zarówno sawari, jak i strumień dźwięku pozostają w nierozerwalnym związku z ciszą (jap. ma).

\section{$M a$}

W dosłownym tłumaczeniu ma to między innymi przestrzeń, pokój, odstęp (zarówno $\mathrm{w}$ czasie, jak $\mathrm{i}$ w przestrzeni), to również czas, właściwy moment. W muzyce słowo to odnosi się do pauzy, interwału. Na skutek tego, że pojedyncze dźwięki traktuje się jako samowystarczalną całość i nie dostrzega się potrzeby łączenia ich, pomiędzy nimi powstaje znacząca cisza - ma, która, jak twierdzi Ta- 
kemitsu, jest czymś więcej niż zwykłym odstępem w czasie czy przestrzeni, ponieważ jest pojęciem filozoficznym (Burt 237). Określenie „cisza” w odniesieniu do czasu między granymi dźwiękami to termin raczej umowny, nie w pełni adekwatny. Cisza $(m a)$ to bowiem czas wypełniony licznymi odgłosami oraz tonami przestrzeni i to ona często gra główną rolę, a dźwięki wydobywane przez instrumenty stanowią jedynie kontrast podkreślający continuum wielu odgłosów będących podstawą utworu. Cisza staje się zatem aktywnym, a nie pasywnym elementem. Tworzenie dźwięku służy wywołaniu niezliczonych odgłosów otoczenia obecnych w ciszy. Właśnie dzięki dźwiękom te inne odgłosy są ożywiane (jap. ma o ikasu), a więc to cisza ma niejako większe znaczenie. Zdaniem Takemitsu:

[...] unikalna idea $m a$ - ta niesłyszalna część [...] muzycznego doświadczenia - zawiera w sobie jednocześnie głębokie, potężne i bogate brzmienie przeciwstawione dźwiękom. Krótko mówiąc to $m a$, ta potężna cisza, jest tym, co daje życie dźwiękom i odbiera im ich uprzywilejowaną pozycję. A więc to ten dźwięk, który staje naprzeciwko ciszy ustępuje jej pierwszeństwa. (Takemitsu, Cronin, Tann 212)

Koncepcje ma i sawari mają wpływ na szczególne podejście Takemitsu do aranżacji jego utworów. Zdaniem kompozytora tradycyjna muzyka europejska, nawet zagrana na innym instrumencie, zachowuje swoją istotę, ponieważ esencjonalna jest w niej struktura. Sedno muzyki natomiast tkwi - według Takemitsu - nie $\mathrm{w}$ braku sztucznych relacji między nutami, ale raczej $\mathrm{w}$ niezgłębionej złożoności dźwięku, która sprawia, że „prawdziwa muzyka w moich kompozycjach nie może być zaaranżowana" (Takemitsu 1995: 144).

Ma zaobserwujemy w bardzo wielu utworach Takemitsu, zarówno tych na flet, gitarę, jak i na fortepian. Cisza, która powinna wybrzmiewać może być dokładnie określona przez kompozytora, jak na przykład w Night (1981) na flet i gitarę ze zbioru Towards the sea (1981). W utworze tym po długiej nucie w partii fletu, przy której zamieszczona jest uwaga w języku angielskim "zanika naturalnie" i w obu partiach instrumentu, pojawia się pauza, a nad nią - zanotowany czas trwania (trzy sekundy). Te wskazówki wytyczają dokładne granice, w których nie ma żadnego dźwięku, a wykonawca i słuchacze mogą stanąć naprzeciw ma. W późniejszych utworach, jak na przykład In the woods (1995), wykonawca niekoniecznie spotka się z tak dokładnymi instrukcjami. Kompozytor zakładał, że muzyka jest już świadomy założeń jego kompozycji i odnajdzie miejsca, w których będzie można doświadczyć ma (Dunlap 9).

\section{Ogrody japońskie, a muzyka Takemitsu}

Przyglądając się tytułom kompozycji, pisanych począwszy od lat siedemdziesiątych, łatwo zauważyć, jak wiele z nich ma związek z naturą. Takemitsu często podkreślał, że wrażliwość na piękno przyrody budziła się w nim w szczególny 
sposób wówczas, gdy przyglądał się japońskim ogrodom. Szczególnie upodobał sobie ogrody, po których można spacerować26, ponieważ to w nich „można swobodnie chodzić, zatrzymywać się, by popatrzeć na cały ogród lub tylko na jedno drzewo. Rośliny, skały i piasek pokazują zmiany, nieustanne zmiany" (Takemitsu 1995: 95).

Podobnie jak John Cage, wspominał niejednokrotnie, że ogrody japońskie stanowią jego wielką muzyczną inspirację. Znane jest stwierdzenie Takemitsu: „Moja muzyka jest ogrodem, a ja jestem ogrodnikiem. Słuchanie mojej muzyki może być porównane do spaceru po ogrodzie, kiedy można doświadczyć zmian oświetlenia, wzorów i faktury [obiektów w ogrodzie]" (Takemitsu 1996).

W rolę "ogrodnika muzyki" wcielił się niemal dosłownie w utworze Arc for Piano and Orchestra, w którym mieszane grupy instrumentów reprezentują poszczególne elementy ogrodu japońskiego (trawę, drzewa, kamienie, piasek). Takemitsu tak jak projektant ogrodu obmyślił dokładnie umiejscowienie poszczególnych części składowych, wskazał rozmieszczenie poszczególnych grup na scenie oraz miejsce dyrygenta. W utworze przewidziane są fragmenty aleatoryczne, do których kompozytor dodał wskazówki wykonawcze w postaci słownego opisu. Muzyka oraz zachowanie muzyków na scenie (w usytuowaniu artystów oczekiwane są zmiany) koresponduje ze zjawiskami występującymi w ogrodzie. A zatem podobnie jak $w$ naturze muzycy reprezentujący na przykład kamienie nie powinni zmieniać swojego miejsca, a partie oraz usytuowanie tych, którzy odpowiadają trawie i kwiatom mają podlegać szybkim modyfikacjom. Przewidziana jest również rola "spacerującego obserwatora", przypisana pianiście. To on w pewnym momencie utworu decyduje o kolejności występu dwóch sekcji instrumentów. Szczegółowe ich rozmieszczenie określone zostaje też w innych utworach. Zamiarem Takemitsu było sprecyzowanie najważniejszych ogniw orkiestry i temu miał służyć z dbałością stworzony plan umiejscowienia instrumentów (Sakamoto 40-46). Arc for Orchestra and Piano nie jest jedynym utworem, w którym kompozytor, odnosząc się do obrazu ogrodu, kładzie nacisk na rozmieszczenie instrumentów.

Pomiędzy Japonią a Zachodem zauważalna jest różnica $\mathrm{w}$ traktowaniu poszczególnych elementów przyrody $w$ ogrodzie. Najbardziej znaczące jest to w przypadku kamieni, które stanowią podstawową cześć każdego rodzaju japońskiego ogrodu. W tradycji europejskiej piękno kamieni wydobywa się przez ich grawerowanie, żłobienie, szlifowanie. Dla Japończyków natomiast ważne jest zachowanie pierwotnego kształtu i faktury kamienia. Ten kontrast upodobań este-

${ }^{26}$ Po japońsku kaiyūshiki teien (ogród spacerowy), rodzaj japońskiego ogrodu zen (wykształconego w okresie Edo, [1603-1868]) o większej powierzchni, w którym często znajduje się staw, wysepki, wzniesienia, charakterystyczna jest też prowadząca wokól, krążąca ścieżka, która umożliwia przechadzkę ze swobodną obserwacją ogrodu z różnej perspektywy. 
tycznych - jak wspomniano - znajduje swoje odbicie w muzyce. Japończycy tworzą ponadto ogrody, starając się zjednoczyć naturę $\mathrm{w}$ ich wnętrzu $\mathrm{z}$ przyrodą znajdującą się poza jego obrębem. Na Zachodnie ogród jest odmiennym światem, zwykle zaprojektowanym w celu stworzenia kontrastu dla budynków. Analogiczne wydaje się podejście Takemitsu do komponowania muzyki. W jego świadomości, świadomości Japończyka, dźwięki instrumentów mają zjednoczyć się z dźwiękami otoczenia, którymi wypełniona jest cisza (ma) (Sakamoto 46-47).

\section{Różnice w sposobie analizy i interpretacji muzyki}

Takemitsu dostrzegał różnicę między zachodnią i japońską muzyką nawet w naturze instrumentów. Analizując muzykę pod tym względem, określał tę zachodnią jako „przenośną". Oznaczało to, że może ona być swobodnie przenoszona w inne miejsce kuli ziemskiej i wykonywana przez miejscowych artystów, czyli że każdy może się jej nauczyć. Muzyka Wschodu Takemitsu określał jako „stacjonarną", ponieważ wykonywanie jej w innym miejscu nie byłoby możliwe bez zauważalnych, istotnych dla kompozytora zmian. Takemitsu wierzył, że tradycyjne instrumenty japońskie, jak lutnia biwa czy flet shakuhachi, nie we wszystkich strefach klimatycznych brzmią odpowiednio i z tego powodu nie są tak uniwersalne jak instrumenty zachodniej orkiestry (Takemitsu 1992: 50). Opinia kompozytora była znana nowojorskim muzykom, którzy podczas prawykonania November Steps w Nowym Jorku wręczyli mu humorystyczną ilustrację „nieprzenośności” japońskich instrumentów. Obraz przedstawiał solistów, którzy, chcąc uchronić te instrumenty przed szkodliwym suchym i zimnym klimatem, zawijają je w ubrania i liście sałaty (Burt 240).

Różnicę między muzyką zachodnią a japońską podkreślał również sposób, w jaki Takemitsu analizował własne kompozycje. Pisząc o niej, rzadko podawał techniczne informacje o muzycznej konstrukcji dzieła i tylko w wyjątkowych przypadkach odwoływał się do przykładów, na których się wzorował. Koncentrował się natomiast na filozoficznym podłożu swoich utworów. Często opisywał je poetyckim, kwiecistym językiem. Nie był zadowolony, gdy zachodni muzycy podejmowali próby skrupulatnej technicznej analizy jego dzieł. Zachęcał natomiast swoich słuchaczy i krytyków do tego, by jego muzykę traktowali bardziej metaforycznie i nie wnikali w zakamarki stosowanych przez niego technik kompozytorskich (Burt 249).

Takemitsu, kładąc nacisk na uzyskanie wyjątkowej barwy dźwięków, dzięki której stają się one wartościowe same w sobie, bez konieczności tworzenia powiązań miedzy nimi, przeczy pojmowaniu muzyki jako struktury, a tym samym uniemożliwił poddanie jej analitycznej metodzie interpretacji. Tworzył wiedziony szczególną wrażliwością na piękno przyrody i sztuki. Dlatego analiza techniczna 
jego utworów nie dostarczyłaby wiedzy o zamysłach autora i jego wyobrażeniu o utworze. Jego intencją zachęcanie swoją muzyką słuchaczy na całym świecie do pobudzania w sobie takiej wrażliwości, która - jak twierdził - jest cechą japońskiego ducha.

\section{Podsumowanie}

Takemitsu Tōru nie odebrał w dzieciństwie i młodości żadnego wykształcenia muzycznego. W jego rodzinie nie było muzyków, ale to właśnie muzyka wyzwalała w nim od dziecka wielkie emocje. W czasie drugiej wojny światowej, będąc jeszcze nastolatkiem, Takemitsu żywił nadzieję, że po nastaniu pokoju uda mu się zostać kompozytorem. Dzięki swojej determinacji i ciekawości zdołał zapoznać się z głównymi nurtami współczesnej zachodniej muzyki awangardowej i zafascynował się nią do tego stopnia, że chętnie czerpał z niej twórczą inspirację. Starał się ponadto, wraz z innymi młodymi artystami, popularyzować tę muzykę w Japonii.

W miarę upływu czasu eksperymenty kompozytorskie Takemitsu budziły coraz większe zainteresowanie na Zachodzie. Wsparcie Igora Strawińskiego i Johna Cage'a, a także współpraca z japońskimi, światowej sławy reżyserami filmowymi wpływały stymulująco na rozwój kariery Takemitsu. Jego twórczość stała się przedmiotem badań muzykologicznych, nie tylko w Japonii. On sam stronił od naukowych analiz swojej muzyki. Wolał ją opisywać, posługując się aluzją, metaforą.

Można przypuszczać, że Takemitsu często odczuwał dyskomfort z powodu różnic w sposobie myślenia ludzi Zachodu i Japończyków. Mimo to zawsze był przekonany o możliwości porozumienia. Pod koniec życia, podczas pobytu w szpitalu, Takemitsu wysyłał swoim znajomym listy i kartki, w których, w typowym dla siebie alegorycznym stylu, zwierzał się, że chciałby „dostać zdrowsze ciało, ciało wieloryba, aby móc pływać po oceanie niemającym ani Wschodu, ani Zachodu" (Burt 234). Wizja ta, choć pozbawiona była nadziei na wyzdrowienie, w piękny sposób ilustruje życiową postawę Takemitsu, a zwłaszcza jego wiarę w uniwersalność sztuki.

\section{BIBLIOGRAFIA}

Burt, Peter. The Music of Tōru Takemitsu. Cambridge: Cambridge University Press, 2001.

Dunlap, Matthew. A performer's guide to Tōru Takemitsu's In the woods. Tallahassee: Florida State Univerity, 2008.

Fujii, Koichi. „Chronology of early electroacoustic music in Japan: What types of source materials are available?". Organised Sound, vol. 9, no. 1 (Kwiecień, 2004). S. 63-67. 
Gianmario, Borio. „Music Facing Up to Silence”. Writings on Tōru Takemitsu. Red. Galliano Luciana. Pawia: Pavia University Press, 2010.

Holderer, Michael J. Japanese Western Classical Music from the Meiji to the Modern Era. Austin: The University of Texas, 2009.

Holmes, Thomas. Electronic and Experimental Music (3'd edition). Nowy Jork: Taylor \& Francis, 2008.

Hughes, Allen. „Concert: Takemitsu, Tashi and Ozawa”. New York Times (1997).

James, Joyce, Finneganów tren. Tłum. Krzysztof Bartnicki. Kraków: Wydawnictwo i Księgarnia Korporacja Ha!art, 2012.

Kusahara, Machiko. „Orgins of Japanese media art- artist embracing technology from 1950's to early 1970's". Odczyt z <http://isea2011.sabanciuniv.edu/paper/origins-japanese-media-art-\%E2\%80 \%93-artists-embracing-technology-1950s-early-1970s>

Music from the Movies: Tōru Takemitsu. Reż. Charlotte Zwerin. Sony Classical Essential Classics, 1994.

Robinson, Elizabeth. Voice, Itinerant, and Air: A Performance and Analytical Guide to the Solo Flute Works of Toru Takemitsu. Municie: Ball State Univeristy, 2011.

Sakamoto, Mikiko. Takemitsu and the Influence of 'Cage Shock': Transforming the Japanese Ideology into Music. Lincoln: University of Nebraska, 2001.

Sakata, Lorraine. „The comperative analysis od sawari on the shamisen”. Ethnomusicology, vol. 10 no. 2 (Maj 1966). S. 141-152.

Schaeffer, Pierre. À la recherche d'une musique concrète. Paryż: Seuil, 1952.

Takemitsu, Tōru. Ki no kagami, Sōgen no kagami (Lustro drzewa lustro trawy). Tōkyō: Shinchōsha, 1975.

Takemitsu, Tōru. Tōi Yobigoe no Kanata e (Za Dalekimi Zawołaniami). Tōkyō: Shinchōsha, 1996.

Takemitsu, Tōru. Confronting Silence: Selected Wraitings. Tłum. KakudoY., Glasgow G. Berkley: Fallen Leaf Press, 1995.

Takemitsu, Tōru. „Contemporary Music in Japan”. Perspectives of New Music, vol. 27 no. 2 (1989). S. 205-214.

Takemitsu, Tōru. „Mirrors”. Perspetives of New Music vol. 30 no.1 (1992). Tłum. Adachi S., Reynoldss R. S. 36-83.

Takemitsu Tōru, Ogawa Seiji. Ongaku (Muzyka). Tōkyō: Shinchōsha, 1981.

Takemitsu, Tōru. Ongaku o Yobimasu Mono (Przywołując muzykę). Tōkyō: Shinchōsha, 1985.

Takemitsu, Tōru, Cronin Tania, Tann Hilary. "Afterword”. Perspectives of New Music, vol. 27 no. 2 (Summer 1989). S. 205-214.

Tezuka, Miwako. „Experimentation and Tradition: The Avant-Garde Play Pierrot Lunaire by Jikken Kōbō and Takechi Tetsuji", Art Journal, vol. 70 No. 3 (2011). S. 64-85.

Tōru, Takemitsu. „Toru Takemitsu: My music is like a garden, and I am the gardener” [Takemitsu Toru: Moja muzyka jest ogrodem a ja jestem ogrodnikiem]. Wywiad przeprowadzony przez Karsten Witt. Wiedeń, 4.11.1993, Soundtrack! Magazine, 1996. 
